\title{
GESCHIEDENIS VAN DE NEDERLANDSCHE BOVENWINDSCHE EILANDEN IN DE 18DE EEUW
}

\author{
DOOR
}

\author{
PROF. DR. L. KNAPPERT
}

HOOFDSTUK V

KERK EN SCHOOL

$\S 15$. Voor de sluiting van een wettig en openbaar huwelijk heeft de gereformeerde kerk altijd geijverd en wij zien haar wezenlijk op haar best bij het rusteloos opkomen voor dit groote volksbelang ${ }^{1}$ ). En gelijk in het vaderland aldus in de overzeesche gewesten. Vóór monogamie, ouderconsent, afkondiging der drie geboden, openbaarheid heeft de Kerk gestreden, tegen bigamie, concubinaat, verboden graden, verlating, twee-gelooven-in-eenhuis niet minder ernstig gewaakt. En door het aanleggen en bijhouden van trouwregisters heeft zij aan tijdgenoot en nageslacht onwaardeerbare diensten bewezen. ${ }^{2}$ ). Voor onze kennis van het volksleven en de volkszeden zijn die trouwboeken eveneens van belang. Van al het gezegde gaan wij nu voorts de bevestiging zien ook op onze eilanden.

Zeer terecht trachtte de Kerk naar de toepassing van het voorschrift omtrent de drie Zondagsche proclamaties, opdat er gelegenheid zou zijn bezwaren tegen het voorgenomen huwelijk in te dienen. Maar tegen dit artikel der huwelijksordonnantie werd zwaar gezondigd. Op St. Eustatius kregen niet alleen de eilanders

\footnotetext{
1) L. Knappert, De ger. kerk in haren strijd om het wettig huwelijk in Ned. Archief II $217-275$ en 359-396 (1903).

$\left.{ }^{2}\right)$ De Heer Ph. van Romondt, vermaagschapt aan tal van oude geslachten op St. Maarten, heeft uit deze en andere bescheiden uitvoerige genealogische aanteekeningen gemaakt over de families Hassell, Salomonsz., Gumbes, Westerband, Richardson, Leverock en mij welwillend gelegenheid gegeven die met de mijne te vergelijken. Ik betuig hem daarvoor hier mijnen hartelijken dank.
} 


\section{NEDERLANDSCHE BOVENWINDSCHE EILANDEN}

zelven en dus althans bij de regeering bekend, maar ook vreemdelingen, tot geheel onbekende matrozen incluis, vaak verlof drie proclamaties op één Zondag te laten gaan, wat toch alleen in zeer dringende gevallen en bij te goeder naam en faam bekend staande personen geoorloofd mocht heeten ${ }^{1}$ ). Wij weten dat aan de Kaap dit menigmaal voorkwam, wanneer de schepelingen op doorreis naar Indië, verloofd geraakt en willende trouwen, haast hadden, omdat de schepen niet wachten konden $\left.{ }^{2}\right)$. Op St. Eustatius vinden wij het euvel in graden. Zoo compareerden 10 November 1765 voor ds. Houwink de Ed. Heer Charles B. Burt, weduwnaar, van St. Christoffel, oud 36 jaar en de jongejuffrouw Petronella Heyliger van het eiland, huwelijksche geboden verzoekende. $\mathrm{Zij}$ legden bewijs over van ouderconsent en nog daarenboven een permit van comm. Jan de Windt, om des daags daarop en twee volgende dagen te worden afgekondigd, waarop zij den 13den dito zijn getrouwd $\left.{ }^{3}\right)$. Op denzelfden 10den November gingen in ondertrouw Jan Jacob de Windt, zoon van den commandeur, oud 23 jaar en Elisabeth Heyliger, oud 15 jaar, kregen hun drie geboden en trouwden ook den 13den $\left.{ }^{4}\right)$. Het kon nog sneller. Den 2den November 1765, een Zaterdag, vroegen Michaël Dickers van Amsterdam en Anna Catharina Hartsen van $\mathrm{S}$. Eustatius de geboden, Zondag 3 werden zij driemaal gelezen en Maandag 4 getrouwd. Ja, Jan Lavaroux, van Londen, 27 jaar en Jane Anna Heyliger, van ons eiland, 16 jaar teekenden dienzelfden 2den November aan, des Zondags gingen alle drie geboden en nog dienzelfden dag werd het huwelijk gesloten ${ }^{5}$ ). Aldus ging het met Jan de Windt en juffrouw Aletta Rinkom, de weduwe van wijlen commandeur Coesvelt, 11 November 1741 gingen de drie proclamaties en op denzelfden dag was het huwelijk; 2 Juli 1745 met Anthony Spen, schipper, en Anna Cove; 18 Augustus 1745 met Bernard de St. George en Maria Markou, „met betaalinge der boete die daarop staat" $\left.{ }^{6}\right)$. De wetsovertreding werd aldus met geld gezoend. Die Anth. Spen was althans schipper, een van die „varende personen", die opmerkelijk talrijk zijn onder de bruidegoms. Zóó Jan Janszen Bay, weduwnaar, van Vlissingen, liggende op de reede van St. Eustatius op het schip de Russische

1) Van Bssen aan classis 6 Nov. 1748, class. arch. Amst., afd. S. E., blz. 15.

$\left.{ }^{2}\right)$ Een voorbeeld met een nichtje van Van Riebeeck in zijn Dagverhaal I 389 vlg.

3) Trouwboek S. E. no. 248 R. A. op 10 Nov. 1765

4) $T \cdot a \cdot p$.

s) Trouwboek no. 248 op 2 Nov. 1765 .

*) Trouwboek no. 252 op data. Het is als de grap van Alida Leevend: drie geboden op één dag en voor 't bed getrouwd, Wolff en Deken. Willlem Leevend, VIII 249. 
Kof met Elisabeth Halleman van ons eiland, maar die hadden geen haast, want 10 April 1728 ging het eerste gebod en den 29 ste trouwden zij ${ }^{1}$ ). Het allersnelst was natuurlijk, wanneer er in het geheel geen geboden gingen. Op den 28sten September 1757 ontving ds. van Essen het volgend briefje van comm. Jan de Windt: „Ik heb den brenger dezes, zijnde Hercules Lewis gepermitteert op heden zig in den houwelijken staat te laaten verbinden met Catharina Wood om reedenen denselve geen verdere uytstel leyden kan”. En de dominee teekent onderworpen aan: „En soo sijn deselve hierop ook op den 28 September getrout, in tegenwoor. digheyt van Thomas Bruett, gerigtsboode, die mij dit bovenstaande heeft behandigt en van Margrita Tonnis zijnde de moeder van Catharina Wood" '2). Gunstige gedachten kan dit alles in geen geval wekken!

Er waren trouwens ook onverdachte redenen voor spoed, maar dan gingen de geboden nog na den trouw. Den 30sten Maart 1754 ondertrouwden Corn. Lespier en Anna Rathery. De moeder der bruid, de weduwe Jeems (van haarzelve) was stervende, waarom, op instandig verzoek der zieke, met speciale schriftelijke volmacht van comm. Jan de Windt en met kennis en goedachting des Eerw. Consistorii de houwelijksche bevestiging nog denzelfden dag aan het doodsbed der moeder plaats vond. Toch geschiedde 31 Maart de eerste afkondiging. „Daarom”, vervolgt het trouwboek, „opdat zoo jemand met reden iets daartegen in te brengen hadde sulks doen mogte. Anders wenschen wij nogmaals daarover des Heeren zeegen" ${ }^{3}$ ). Even gemoedelijk ging het toe met het huwelijk van Isaäc vạn Dam en Sally Young (voorbeeld meteen van den geschonden staat der trouwregisters) "getrouwt op order van den Heer Gouverneur Jan de Windt op denzelfden avont op welke de ondertr.... . hiet, zijnde de bruyt zeer ....k. Deze persoonen zijn door mij des avonds om ... gen uur getr.... en wel op uytdrukkelijk b.... van S. E. op den 9 Dec. .... de bruyt niet . . 1, dog de geboden zullen egter gaan" $\left.{ }^{1}\right)$. Nog lees ik van een huwelijk, "liggende de bruid ziek aan de kinderpokjens" ${ }^{2}$ ).

Tegen lichtvaardige afbreking van het plan ten huwelijk waak-

1) Trouwboek no. 251 op datum.

2) Trouwboek no. 252 op 28 Sept. 1757.

3) Trouwboek no. 252 op 30 Maart 1754.

1) Trouwboek no. 253 op 9 Dec. 1767.

$\left.{ }^{2}\right)$ Trouwboek no. 254 op 3 Febr. 1776. In de eerste maanden van dat jaar heerschte er op het eiland eene vreeselijke pokkenepidemie, Wildrik aan classis 5 Junl 1776, oud class. archief afd. S. E. blz. 33. 


\section{NEDERLANDSCHE BOVENWINDSCHE EILANDEN}

te de Kerk. Op St. Maarten hadden Absalom Seagers en Joanna Ens reeds twee proclamaties gehad, toen zij ontslag van den gedanen ondertrouw vroegen. De kerkeraad stond hun dat toe, mits zij aan meester Andries Vis voor twee dagvaardigingen 2 stuivers en aan den predikant $f 5$ betaalden. Ds. Stauffer schonk die som aan partijen ${ }^{1}$ ). In dezelfde familie moest een bruidspaar herinnerd worden aan het weduwenjaar. Mary Seagers, weduwe van Benjamin Westerband, overleden 17 Maart 1791, was in Augustus reeds weder ondertrouwd met William Sochnesz. jongman. Dit was in strijd met het Echtreglement voor de Generaliteitslanden van 18 Maart 1665 artikel 52, waar staat dat „weduwen onder de vijftigh jaren sullen onderhouden annum luctus en binnen de negen maanden na harer mannen doodt niet mogen trouwen" 2). De Eerw. kerkeraad liet derhalve partijen voor zich dagvaarden en verbood hen te trouwen of te cohabiteeren vóór negen maanden na 17 Maart op straffe volgens de wet ${ }^{3}$ ).

$\S 16$. Wij hebben indertijd melding gemaakt van het verzet van John Philips tegen het huwelijk zijner dochter ${ }^{4}$ ). Het reeds vermelde huwelijk van Anna Catharina Seijs, dochter des ouderlings ${ }^{5}$ ), vond bij den vader ook tegenkanting, verklarende „de vader des bruids (sic) 't huwelijk met $\mathrm{ZE}$. genoegen niet te zijn edogh de bruid mondig zijnde zulks niet te kunnen beletten" ${ }^{6}$ ). De bruidegom was luthersch en misschien had ouderling Seys daartegen bezwaar. Hier was dus het ouderconsent onnoodig. Waar het geweigerd en de weigering onbillijk bevonden werd, kon de kerkeraad het huwelijk nochtans laten doorgaan. Op St. Maarten stond Nicolaas Violones jun. onder de geboden met Hannaritha Margaritha Buscher toen de vader, Nicolaas Violanes sen. ze stuitte. De kerkeraad dagvaardde beiden vóór zich tegen Vrijdag 12 Augustus 1791. Maar op dien dag kwam Nicolaas jun. zeggen, dat zijn vader onpasselijk was, waarop hem werd verleend eerste défault met tweede dagvaarding tegen 19 Augustus. Inderdaad stond toen Nicolaas sen. binnen en verklaarde dat hij de geboden gestut had, omdat de bruid mesties was. Toen daarop ds. Stauffer hem zijne acte van consent toonde, zeide de

\footnotetext{
1) Not. kerker. St. Maarten 27 Mei 1792 sub 3. R. A. Inv. no. 533.

$\left.{ }^{2}\right)$ Kerkelijk Plakaatboek I 831. Over het annus luctus uitvoerig in mijn art. Ned. Archief II, 1903, blz. 385 vlg.

3) Notul. kerker. St. Maarten 8 Augustus 1791, sub. 3 R. A. Invent. no. 533. Zó ook de Raad des eilands, scabin. acten, archief no. 296. Reeds den 11 den April van dit jaar had zij den dubieusen boedel van Benjamin geweigerd, aldaar no. 196.

4) Boven, IV § 29.

s) Boven, $\mathrm{V} \S 9$.

๑) Trouwboek S. E. no. 254 op 17 Jan. 1784.
} 
man dat hij dat stuk had gezien noch geteekend, daarbij voorts bekennende dat zijn zoon geen wettig kind was. De kerkeraad delibereerde en (zonder dat wij de eigenlijke reden vernemen) ,is Nicolaas senior verklaard quade opposant, gecondemneerd het huwelijk niet te verhinderen, maar aan koster Andries Vis te betalen $f 5-4-0$." De derde proclamatie zou voortgang hebben en de predikant het huwelijk sluiten. Daar echter Nicolaas sen. onvermogend was, zouden diakenen uit de armkas den koster zijn $f 5.20$ voldoen ${ }^{1}$ ).

$\S 17$. Het verhinderen van bigamie was zeker uiterst bezwaarlijk op eilanden, waar zooveel vreemdelingen uit alle 's Heeren landen langer of korter verblijf hielden, of alleen maar voor hun huwelijk schenen te komen, zooals b.v. Jacobus Sm. . geboren in Londen en wonende op Antigua en Elisabeth Jeamen j.d. geboren in Frankrijk en wonende op St. Thomas ${ }^{2}$ ). Behalve vooreerst talloozen uit Engeland, Schotland, Ierland en Wales, vinden wij vele Franschen, zooals die Monsieur Jean Laconderer van St. Foy (Gironde) j.m. 30 jaar, die met niemand minder trouwt dan met Elisabeth de Windt, dochter des commandeurs j. d. gaande in het zestiende jaars haars ouderdoms ${ }^{3}$ ). Dan Italianen zooals Francisco Girco uit Florence, die met Elisabet Meyers in het huwelijk treedt ${ }^{4}$ ); of Zweden, zooals Christiaan Detloff Homberg van Straalsund onder Zweedsch gebied j. m. 27 j. en Petronella de Ladoiré van Bordeaux ${ }^{5}$ ). Ik vind zelfs een bruidegom heel van Jeruzalem ${ }^{6}$ ). Stellig waakte men tegen bigamie, en misschien slaat daarop de soms voorkomende aanteekening, , ,dit huwelijk is door den Raad verboden" " ). Ook bestond het gevaar, dat vreemdelingen hun huwelijk door verlating verbraken. Zoo trouwden Jean Thibaudeau en Helena Catharina Gijssen, zijnde de bruid getrouwd geweest met een Franschman, die Odet de Coligny heette, maar die haar „malitieus" verlaten had $\left.{ }^{8}\right)$. Zulke verlatingen vinden wij echter ook van eilanders zelven vermeld

1) Notulen kerker. S. Maarten 19 Aug. 1791 sub 1.

$\left.{ }^{2}\right)$ Trouwboek S. E. no. 251 op 24 April 1712.

3) Trouwboek S. E. no. 252 op 1 December 1759.

4) Trouwboek S. E. no. 253 op 11 Juli 1767.

s) Trouwboek S. E. no. 254 op 20 Mei 1786.

6) Trouwboek S. E. no. 253 op 2 Maart 1771.

7) Trouwboek no. 254 op 26 Sept. 1784.

$\left.{ }^{8}\right)$ Trouwboek S. E. no. 252 op 20 Mei 1758. Natuurlijk valt de beroemde naam Odet de Coligny op. De groote Gaspard had als admiraal van Frankrijk expedities naar Florida in 1562 en 1565 uitgezonden, maar ze mislukten en het is zeer onwaarschijnlijk dat deze man daarmeê in verband zou staan. Het mannelijk oir des admiraals stierf in 1657 uit met Henri Gaspard. Van Odet ken ik geen nakomelingen. Misschien heeft een gewone avonturier zich met den beroemden naam getooid. 


\section{NEDERLANDSCHE BOVENWINDSCHE EILANDEN}

en dan tijdens den ondertrouw, zooals die James Runnels, die 17 April 1779 in ondertrouw werd opgenomen met Mary Elisabeth Stodges, maar sedert het eiland verliet en niet was teruggekeerd. Het meisje beviel 25 September 1779 van eene dochter, die eindelijk, toen de vader niet terugkeerde, 7 Januari 1780 werd gedoopt ${ }^{1}$ ).

De vreemde nationaliteiten brachten ook het verschilvan godsdienst en dus de gemengde huwelijken. Om dit niet in de hand te werken bepaalde de Raad, dat, wanneer Roomschgezinden met Protestanten trouwden, de geboden van 6 tot 6 weken gaan moesten. Toen dus Guillaume Lacombé van Dijon en Elisabeth Aertssen van ons eiland 26 Juni 1779 aanteekenden, ging het eerste gebod 27 Juni, het tweede 8 Augustus, op welken dag ook het huwelijk voltrokken werd ${ }^{2}$ ). Heel streng hield men er zich trouwens niet aan. Toen Seb. Basier, roomsch, en Anna Oyen, protestant, 26 September 1784 hun eerste gebod kregen, ging het tweede reeds 2 October, dat de bruidegom toen stuitte ${ }^{3}$ ). In het „Trouwprotocol des eilands St. Eustatius" van ds. J. H. Reneman vindt men nu ook de gezindten aangeteekend, "zijnde roomsch van geloof”, of „van gereformeerde religie”, of (gewone vergissing, ook tegenwoordig nog dikwijls) „bruidegom luthersch, bruid protestant" 4), terwijl natuurlijk gereformeerd bedoeld wordt. Gelijk, naar wij zagen, geestelijken van andere kerkgenootschappen doopten, trouwden zij ook. Tijdens een reis van ds. Wildrik naar Holland machtigde commandeur De Windt den Engelschen predikant Richardson om huwelijken te sluiten ${ }^{5}$ ). Door katholieke priesters gesloten huwelijken schreef men zonder meer in: „Antoine Vincent Telmont de St. Joseph en Marie Catharine Pimont van St. Martin in het Fransche Quartier zijn aldaar getrouwt volgens de gewoonten van dat lant of roomsche kerkgewoonte. Zijnde het huwelijk gecelebreert door den Capucijn Hypolite pastor loci. De trouwcedul was geteekend 28 November $1775 \mathrm{Du}$ Carné Tresesson" 6). Waren er in het geheel geen geestelijken, dan nam de overheid hun werk over. D.w.z. het huwelijk kon, juist als in patria, alleen burgerlijk zijn, en de bekende commissarissen

\footnotetext{
1) Doopboek no. 250 op 7 Januari 1780 .

2) Trouwboek S. E. no. 254 op 26 Juni 1779. Weder als in de Generaliteitslanden, mijn art. in Ned. Archief II, 1903. blz. 271.

3) Trouwboek S. E. no. 254 op 26 Sept. 1784

4) Trouwboek S. E. no. 254 op 5 Juli 1783.

5) Trouwboek S. E. no. 253. Op een zeer geschonden blad waarboven 1774 . Ds. W. schrijft over zijn voorgenomen reis aan classis 9 Nov. 1772, oud class. archief afd. S. E blz. 31 .

6) Trouwboek S. E. no. 254 op 7 Febr. 1776.
} 
tot de huwelijksche zaken hielden aanteekening van de geboden, zoowel van gereformeerden die voor den predikant als van alle soorten dissenters die voor schepenen zouden trouwen, terwijl zij bovendien als huwelijkshof toezicht hielden op de naleving der huwelijksordonnantie. Dit college bestond insgelijks in de overzeesche gewesten, maar op onze eilanden vond ik er niet opzettelijk melding van gemaakt. Maar de practijk ervan was er evenzeer. Want toen er b.v. sprake van was, dat ds. Houwink van St. Maarten naar Curaçao zou gaan, schreven de Heeren aan den vice-commandeur Abr. Heyliger, dat gedurende de vacature alle huwelijken, zonder onderscheid van confessie, ten overstaan van commandeur en raden behoorden gesloten te worden op straffe van onwettigheid $\left.{ }^{1}\right)$.

$\S 18$. Wij spraken van vreemdelingen die zich op onze eilanden lieten trouwen. Het omgekeerde kwam ook herhaaldelijk voor. Vele paren, om aan de bepalingen van het vaderlandsche huwelijksreglement te ontkomen, gingen met name naar St. Christoffel, waar de Engelsche predikant van Sandy Point hen trouwde, hetzij minderjarigen, die geen ouderconsent konden toonen, hetzij lieden die in concubinaat leefden, en dat zoo maar, als een andere smid van Gretna Green, voor de hand weg, tegen vier pistolen ${ }^{2}$ ). Zonder twijfel was dat verkeerd, maar het is de vraag, of het voorgestelde middel zou gebaat hebben, dat nl. geen inboorling zou mogen trouwen vóór hij geloofsbelijdenis had afgelegd ${ }^{3}$ ). In elk geval zou er grooter samenwerking tusschen de onderscheiden eilanden moeten geweest zijn. En die was er zelfs niet altijd tusschen de onze. Den 11den Mei 1792 waren op St. Maarten getrouwd Diederik Noteboom, pakhuismeester en soldijboekhouder, geboren te Montfoort, laatst gewoond hebbend te Waddingsveen en Sara Maria de la Chari van St. Eustatius. Ds. Brill had hen op dat eiland hunne proclamaties geweigerd, ds. Stauffer van St. Maarten hen nochtans getrouwd. Diederik verzocht toen, dat de kerkeraad een extract uit het trouwboek naar St. Eustatius zou zenden om aldaar in de kerkelijke protocollen te worden geïnsereerd. En inderdaad wendde de kerkeraad zich ten dezen met een brief aan Pieter Anthony Godin, commandeur en president des kerkeraads op St. Eustatius ${ }^{4}$ ).

\footnotetext{
$\left.{ }^{1}\right)$ Kamer Amst. aan Heyliger 28 Maart 1764, 7 Mei 1765, 342 W. I. C. 475. Vandaar ook af en toe de aanteekening, „dit huwelijk voltrokken door Gouverneur en Rade”.

$\left.{ }^{2}\right)$ Van Essen aan X 2 Mei 1744 , port. no. 6 fol. 185 r. Dez. aan classis 6 Nov. 1748 , oud class. archief afd. S. E., blz. 15 .

3) Van Essen aan X 30 Jan. 1744, port. no. 6, fol. 130r.

4) Notulen kerkeraad St. Maarten 27 Mei 1792 sub 2. R. A. Invent. no. 533. Of de inschrijving heeft plaats gehad kan ik niet nagaan: het laatste huwelijk in het trouwboek van S. E. is d.d. 12 Nov. 1791.
} 
Wij hebben vroeger bericht, dat ds. Robberts, op St. Christoffel getrouwd, naar Nederlandsche wetten zich liet overtrouwen ${ }^{1}$ ). En dit kwam begrijpelijkerwijze meer voor blijkens de aanteekening: ,hebbe ik op order van den gouverneur getrouwt.... welke persoonen voor veele jaaren reets onder de Engelschen zijn getrouwt geweest" ${ }^{2}$ ). Maar minder duidelijk is mij de reden van een overtrouw in Nederland. De Heer Alexander Le Jeune, geboortig van Bergen op Zoom en secretaris des eilands was 12 Augustus 1776 getrouwd met Maria Huurman geboren te Schiedam. Drie jaar later, 6 September 1779, schreef hij aan ds. Schwiers en verzocht de huwelijksche geboden van hem en Mej. Huurman af te roepen, zijnde hij voornemens, alhoewel dien 12en Augustus 1776 door den Weleerw. Heer R. Wildrik na voorafgaande proclamaties getrouwd, zich in het vaderland hertrouwen te laten. Ds. Schwiers voldeed aan het verzoek en 12, 19 en 26 September zijn de geboden gegaan en ongehinderd afgeloopen ${ }^{3}$ ). Ik kan dit niet verklaren. In 1776 was Le Jeune secretaris geworden in plaats van Joh. de Graaff, die tot commandeur was benoemd. Zij konden het samen zoo slecht vinden, dat De Graaff Le Jeune ontsloeg, al gelastten de Heeren hem dat ontslag oogenblikkelijk te herroepen ${ }^{4}$ ). Maar dit verklaart niets.

Bekend is de gewoonte van toen, om een kind, vóór het huwelijk geboren en dat men wilde echten, bij de huwelijkssluiting tusschen zich in te nemen. Op ons eiland lees ik meest niet anders dan ,getrout en een kind geëgt”. Slechts zie ik, dat, toen Cornelis Boy en Sara Jeems 10 Juli 1788 trouwden, zij aan de hand tusschen hen beiden in hun dochtertje Elisabeth hadden ${ }^{5}$ ).

Den leeftijdsgrens, twaalf jaar voor het meisje $\left.{ }^{6}\right)$. heb ik niet overschreden gevonden. Wanneer wij op onze eilanden herhaaldelijk bruiden vinden van 15 en 16 jaar, behoeven wij dat niet aan het tropisch klimaat toe te schrijven. Van de eigenlijke kinderhuwelijken spreek ik hier niet, maar in het 18de eeuwsche Twenthe kennen wij immers jong gehuwde mevrouwtjes van 15 en 16 jaar, te zamen op een ,snieboonendeun" 7).

1) Boven, V § sub 3.

2) B.v. Trouwboek S. E. no. 254 op 2 Juni 1776.

3) Trouwboek S. E. no. 254 op 26 Juli 1776 en 6 Sept. 1779.

4) Heeren X aan De Graaff 30 April, 1 Mei, 28 Juni 1778, 111 W. I. C. 74.

5) Trouwboek S. E. no. 254 op 10 Juli 1788 . Over de gewoonte, vóór de Reformatie, mijn gen. art., blz. 391. Onwettig geborenen worden gewettigd door het huwelijk der ouders, De Groot, Inleidingh t. d. Holl. Regtsgel. I, 12, 9.

$\left.{ }^{6}\right)$ De Groot, a. w. I, 5, 3. Mijn gen. art. blz. 247.

$\left.{ }^{7}\right)$ C. Elderink, Een Twentsch fabriqueur 1923, blz. 7. Aleida Leurink was 15 jaar toen zij met ds. H. Keller van Losser trouwde, J. J. van Deinse, $U$ it het land van katoen en heide, 1925, blz. 56 vlg. 
§ 19. Diakenen vinden wij het werk doen, dat wij van hen verwachten. $Z_{i j}$ beheeren de diakoniekas $\left.{ }^{1}\right)$. Ook heeft de diakonie bezittingen b.v. slaven. Ik lees van een gedoopt kind, Charles, waarvan de vader, Jan Louis, behoort aan juffrouw Blake en de moeder, Rachel, een negerin aan de diakonie ${ }^{2}$ ). Voorts ondersteunen zij allerlei behoeftigen. Er was tegen het eind der eeuw op St. Maarten eene vrouw, Lettica Martin, die wij aan de diaconie $f 22$ zien vragen voor het cureeren van Catharina en Walther Gray. Men betaalt haar het bedrag uit, zonder dat blijkt, waarin dat cureeren bestond ${ }^{3}$ ). Dezelfde vrouw had ook diakoniekinderen bij zich thuis; voor William Brown vroeg zij $f 5-4-0$ in de maand, maar diakenen vonden drie daalders genoeg en gaven haar over elf maanden $\left.f 45-3-0{ }^{4}\right)$. Dezelfde ,moderatie” pasten zij toe op de rekening van Frederik George Eyman, M. D., die voor de behandeling van "diverse" armen eene nota had ingediend van $f 91-4-0$ doch aan wien uit de armegelden $f 77$ zou worden uitgekeerd ${ }^{5}$ ). En hier is Elizabeth Sochnesz., die aan diakenen mededeelt, dat de nagelaten kinderen van Edward Rilvy, in den orkaan van 1786 vergaan, Johanna en Maria, zeer nooddruftig zijn, waarop de broeders aan ieder van haar uit de armenkas $f 2-6-0$ in de maand toeleggen $\left.{ }^{6}\right)$. Nic. Willem's Jacob, dien wij reeds als diaken kennen ${ }^{7}$ ), hooren wij rapporteeren over Jane Dasy, eene ongehuwde dochter, aan ééne zijde verlamd; diakenen geven haar $f 4-1-0$ in de maand $\left.{ }^{8}\right)$. Juist zooals het in een of ander vaderlandsch dorp gaan zou.

$\S 20$. Op de deputaten van Amsterdam, Middelburg, Delft en Rotterdam rustte de briefwisseling met de Oost-Indische gemeenten d.w.z. van lieverlede alleen met den kerkeraad te Batavia, die de berichten aan de andere kerkeraden doorzond $\left.{ }^{9}\right)$. Met onze eilanden stond in de 18de eeuw classis Amsterdam in briefwisseling, zooals ons reeds herhaaldelijk gebleken is. Hebben over het algemeen de W. Indische predikanten trouw en uitvoerig ge-

$\left.{ }^{1}\right)$ Reneman aan classis 2 Juli 1783, oud class. archief, afd. S. Maarten, blz. 44. De kas heet daar ledig. Het verbaast ons niet, wanneer wij b.v. zien dat vermogende burgers als Laurens Westerband en Anna Leverock in hun testament van 19 Jan. 1781 aan de diakonie legateeren... 5 pesos. Scabin. acten St. Maarten, Archief no. 187 .

$\left.{ }^{2}\right)$ Doopboek S. E. no. 250 op 6 Juli 1779.

3) Notulen kerker. St. M. 12 Aug. 1791 sub. 2, 19 Aug. sub 2.

4) Notulen als boven, 27 Mei 1792, sub 5.

5) Notulen als boven 19 Aug. 1791, sub. 3.

6) Notulen als boven $27 \mathrm{Mei} 1792$, sub 4.

7) Boven, $\mathrm{V} \S 9$ in fine.

8) Notulen als boven 27 Mei 1792, sub 6.

9) Van Boetzelaer van Dubbeldam, a. w., blz. 99. 


\section{NEDERLANDSCHE BOVENWINDSCHE EILANDEN}

schreven, de classis was minder plichtmatig. Telkens en telkens hooren wij, dat zij maar niet antwoordt, en wanneer zij het doet, dan treft ons hetzelfde dat van de brieven naar Oost-Indië gezegd wordt, er is niet meer die warme belangstelling, dat ingaan in en medeleven met alles wat in Indië gebeurde, die in het begin zoo weldadig aandoen ${ }^{1}$ ). De predikanten van hunne zijde schrijven aan de classis niet zóó onderdanig als zij dit den Heeren doen. In een brief aan X eindigt een hunner: „Hoch Edle Groot Achtbare Heeren! De Heere Godt gedenke aller uwer spijsofferen ende maake uwe brandofferen tot assche. Sela!" $\left.{ }^{2}\right)$ Dat Sela als bekrachtiging is kostelijk. Of nogeens: „Beveele de H. E. ende Gr. A. Heeren te zamen en in het bijzonder onder de vleugelen des Allerhoogsten. Hij overschaduwe UE. met de schatte van algenoegsaamheid en geve U.E. Gr. Achtb. seegen ende welvaerdt in lengte van dagen ewiglijk en altoos en teekene mij met de diepste veneratie.." ${ }^{3}$ ) Aan de briefwisseling met de classis had het hart zijn deel. Het heet: „Eene goede tijding uit een ver land is als koud water op eene vermoeide ziel” " $)$. Of ook: „Niets zal mij aan deze zijde der grogte wateren aangenamer zijn dan aanhoudende correspondentie" 5). En dan het gevoel van eenzaamheid: „Na de laatste tijdinge hangen de protestantsche kerk zware wolken der ellende over het hoofd en bij rupture zouden wij op dit eiland komen te zijn en te zitten als een vogel op een takien. De Heere beware ons voor list en overval van vijanden!"' ${ }^{6}$ ) Af en toe durft de teleurstelling zich uiten: „Al maar gehoopt en verlangd naar eenig antwoord. Het goede gedrag noch het uiterste devoir van een predikant helpt hier zonder steun der Heeren, hoewel H.E. Gr. A. nae haer beschaaft verstand in die behoorlijke verbeelding sijn" ${ }^{7}$ ). Dit was tot Bewindhebberen gericht. Even aangenaam is de openhartige toon, dien ds. Henr. Müller van St. Kruis tegenover de classis durft aanslaan, wien wij deswege zijn Duitsch Nederlandsch gaarne vergeven: „.....Ik, een jong leeraar neem de vrijheid.... opdat ik door $U$ raad moge ontvangen.... Nu wil ik door classis onderricht worden en verwacht niets minder als dat de antwoord terug blijven zouden. Ik wil

\footnotetext{
1) Van Boetzelaer a. w. ,blz. 101.

2) Van Essen aan X 21 Nov, 1744, port, no, 6, fol. 300 v. Boven, I \$ 13 in fine.

3) Van Essen aan X 12 Juni 1745, port. no. 6, fol. 505 v. Schatten, schaduw.

4) Van Essen aan classis 27 Octob. 1750, oud class. arch. afd. S. E., blz. 16. Vergel. Spr. 25, 25 .

5) Van Essen aan classis 15 Febr. 1755, aldaar blz. 19.

s) Uit denzelfden brief. Van Essen aan X 20 Febr. 1742: „In krijgstijd zouden wij hier niet anders zijn als een vogeljen op een takjen", port. no. 5, fol. 523 .

$\left.{ }^{2}\right)$ Van Essen aan X 12 Juni 1745, port. no. 6, fol. 505 v.
} 
gaarne onderricht worden, maar behandel mij niet als iemand die de kerkorde zoekt te violeeren. Als jongere past mij uwen raad te volgen, maar als Deensch onderdaan kan niemand mij tot gehoorzaamheid aan classis verplichten. Voor complimenten schrijven heb ik geen tijd en papier, maar beiden zoeken wij der kerke Christi nut te doen" '). En dan ook hier de teleurstelling over de clasicale traagheid: „Wij zouden wel eerder geschreven hebben, maar kregen van $U$ op voorgaande brieven nimmer antwoord. Hoe zit dat toch? Maar wij zullen desniettemin onzen plicht doen en schrijven" ${ }^{2}$ ).

Was de classis in het schrijven traag, geregeld zorgde zij voor de toezending der synodale acta van Noord-Holland; de exemplaren voor St. Thomas, St. Jan en St. Kruis gingen via St. Eustatius ${ }^{3}$ ).

$\S 21$. Wij hebben reeds terloops gesproken van het leertuchtproces tegen ds. John Runnels en moeten daarover thans opzettelijk handelen. Hij was van een Statiaansch geslacht, waarvan wij onderscheiden leden kennen ${ }^{4}$ ), ging voor de studie naar Holland en wij vonden hem 1759 als student te Utrecht ${ }^{5}$ ). Naar zijn eigen zeggen heeft zijn behuwdoom, wijlen ds. Longueville, hem tot lidmaat der Engelsch Geref. kerk te Amsterdam aangenomen, wat dus wel Rev. David Longueville zal geweest zijn, die, van Exon gekomen, sinds 17 Juli 1740 te Amsterdam stond $\left.{ }^{6}\right)$. Na zijn studietijd is Runnels naar zijn eilanden teruggekeerd, want, toen ds. Barak Houwink in Januari 1763 op St. Maarten gekomen was en bevonden had, dat de meesten geen Nederlandsch meer verstonden, viel de aandacht op Runnels als Engelsch leeraar en Houwink stond hem toe te doopen en te trouwen wie het Nederlandsch niet machtig waren ${ }^{7}$ ). Natuurlijk ontstonden hieruit moeielijkheden. Houwink vond den man „ambitieus”, hij had een volmacht van de Engelsch Presbyt. kerk om te mogen doo-

1) Henr. Müller aan classis d.d. Christinstadt, St. Kruis, 15 Jan. 1775. Oud class. arch. afd. St. Croix, blz. 1 .

${ }^{2}$ ) Henr. Müller aan classis d.d. Christianstadt 5 Juni 1776, archief en afd. als boven.

3) Van Essen aan classis 19 Aug. 1762; Wildrik aan classis 28 Juli 1768; 28 Mei $1770 ; 14$ October 1775, oud class. archief afd. S. E., blz. 25, 27, $29,32$.

4) Aletta Doeke Francina R. ged. 3 Maart 1788 Doopb. no. 250. Anna Catharina R. vr. v. Isaäc Groebe, Doopboek no. 248 op 10 Jan. 1765. Anna Maria R. vr. van Jan Hendrik Sieben, Doopb. no. 247 op 26 Dec. 1715. Catharina R, ged. 10 Jan. 1765. George R. vader van Cath., aldaar. Isaäc Runnels als overl. vermeld Doopb. no. 253 op 8 Febr. 1773. Jacob Creagh Heyliger R., ged. 25 Oct. 1787, Doopb. no. 250 op datum. James R. boven blz. 361. Johannes R. gouv. a. i. Doopb. d . 250 op 3 Maart 1788. Joh. Hendrik R ged. 8 Apr. 1789 aldaar op datum. Van onzen ds. John R. en zijn gezin boven, blz. 189 .

5) Boven, blz. 477 .

6) Wagenaar, Amsterdam, II $175 a$.

?) Houwink aan ds. Kesseler 20 Febr. 1763, oud class. archief, afd. S. M., blz. 1. 
pen en wilde zich niet onder den Nederlandschen pastor loci voegen. Bovendien beteekende elke huisdoop, door hem verricht, schade voor Houwink ${ }^{\mathbf{1}}$ ), doch in dat opzicht gedroeg Runnels zich althans correct, hij weigerde alle belooning, wat hem trouwens niet moeielijk viel, omdat hij het zeker hooge tractement van 1400 pesos ontving. En dan blijkt, dat hij niet rechtzinnig was. Volgens Houwink ontkende hij het "peccatum originale”, nam althans den vrijen wil aan, om na den val het Evangelie te kunnen gehoorzamen. „Dus”, zegt deze inquisiteur, „hauwde (sic) ik hem voor pelagiaan, semipelagiaan of remonstrant". Met de socinianen leerde hij bovendien dat de mysteriën van den godsdienst door de rede kunnen gekend worden. Kwaad was het ook, dat hij kettersche geschriften verspreidde met name „Bard, Appel aan het oordeel". Ik ben geneigd bij dezen naam te denken aan den befaamden Carl Friedrich Bahrdt, den Duitschen deïst, die „een unitaris was in de leer van Vader, Zoon en Geest, pelagiaans gezind in de leer van 's menschen verdorvenheid en sociniaansgezind in de leer der voldoening"' ${ }^{2}$ ). Een bezwaar daartegen is

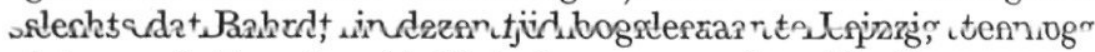
niet voor kettersch gold. Dat vice-commandeur Heyliger en ouderling Bousjon (sic; Beaujon) Runnels ook onrechtzinnig vonden, hield ds. Houwink voor een even krachtig getuigenis als van twee professoren aan een onzer hoogescholen ${ }^{3}$ ).

Zondag 25 September 1763 nu preekte Runnels voor zijne Engelsche gemeente en noemde toen de leer, dat God de auteur der zonde is, "grouwelijk". Deswege voor den kerkeraad gedaagd, weigerde hij in een "impertinenten” brief te verschijnen. Maar Heyliger, Beaujon en John Salomons Gibbes getuigden eenstemmig, dat hij de praedestinatie loochende, omdat men anders den mensch tot een steen of machine zou maken en God tot een auteur van het kwaad. De vice-commandeur voegde daar nog bij, in later jaren, dat hij toentertijd reeds had getuigd, dat ook ds. N. Clay van Anguila zeide, dat Runnels de leer der H. Drieëenheid weersprak en deswege ook nimmer de Drie formulieren had willen onderteekenen. De kerkeraad, nog bovendien overwegende, dat de Engelschen hem wel is waar als predikant hadden geroepen, maar dat hij nooit was bevestigd en ook geen eigen kerkeraad had, verboden hem alle prediking, waar ook, totdat hij zijne dwalingen zou hebben herroepen. De commandeur van

\footnotetext{
1) Boven, blz. 483.

$\left.{ }^{2}\right)$ A. Ypey, Gesch. v. d. Krist. Kerk i. d. I8de eeuw, II 249. Zie verder aldaar het register i. $\mathbf{v}$.

3) Houwink aan ds. Kesseler 6 Mei 1763, oud cl. archief als boven, blz. 2, 3 .
} 
St. Eustatius wijzigde dit vonnis in zooverre, dat het prediken buiten de kerk hem bleef toegestaan $\left.{ }^{1}\right)$. Inderdaad verzachtte ook hier de Staat het vonnis der Kerk, en wij vinden Runnels als predikant der Engelsch Presbyteriaansche gemeente van St. Maarten preeken, doopen en trouwen in 1765, 1771, 1775, tot 1777 toe, in welk jaar hij rustend heet ${ }^{2}$ ).

Maar toen rees ook bij hem het plan, nu de jaren hem weer behoudender hadden gemaakt, om zich te laten rehabiliteeren. Hij wilde naar Amsterdam, daar van de classis na onderzoek eene aanbeveling ontvangen (d.i. commendatus classis worden) en daarna als wettig presbyteriaansch predikant op St. Eustatius dienst doen. Men hoorde dat op het eiland met gemengde gevoelens, omdat men er voor de Nederl. Geref. gemeente nieuwe moeielijkheden van vreesde ${ }^{3}$ ). Maar Runnels deed de reis en stond in Maart 1779 binnen voor den kerkeraad der Engelsch Geref. gemeente te Amsterdam, praeses Thomas Peirson 4). Na het onderzoek ontving hij eene attestatie, d.d. 20 Maart, waarin te lezen stond, dat John Runnels, Phil. en S. S. Th. D., de 37 artikelen aanvaardde, getrouw was in het hooren des Woords, mitsdien overal tot het avondmaal mocht worden toegelaten, en aan het slot de bede, hem, waarheen zijn lot hem ook zou brengen, goed te ontvangen. Met dit stuk was hij in September reeds weder in de kerkeraadsvergadering op St. Eustatius en verzocht thans tot het avondmaal te worden toegelaten ${ }^{5}$ ). De kerkeraad ging daarop echter niet in en de zaak bleef slepend. Toen kwam Rodney's overval in Februari 1781 en de Engelsche Episcopale predikant nam de gereformeerde kerk in gebruik. Nog vóór het einde des jaars veroverde de markies De Bouillé, gouverneur van Martinique, St. Eustatius weder op de Engelschen en zegde aan Reneman en Runnels bescherming hunner kerk toe. Deze laatste wendde zich toen maar weer tot de classis. Hij had middelen om te leven en het was dus geen eigenbaat die hem dreef, wanneer hij op verzoening met de classis, ten aanzien van de leergeschillen van 1763, aandrong. Ja, hij was toen ook van röellianismus en de leer van

\footnotetext{
1) Notulen kerkeraad S. Maarten 29 Sept. 1763 met copie van den brief van Runnels, het getuigenis der drie genoemden, een extract uit de preek en nog twee brieven van Houwink aan classis d.d. 27 en 29 Oct. Getuigenis van Abr. Heyliger Pzn., d.d. 22 Maart 1779, oud class. archief als boven, blz. 4,12, 17.

$\left.{ }^{2}\right)$ Doopboek S. E. no. 250 op 18 Juni 1777.

${ }^{3}$ Conr. Schwiers aan classis d.d. S. E. 27 Mei 1778, oud class. archief, afd. S. E. blz. 34 .

4) Thomas Peirson SS. Th. D. was in 1777 Engelsch predikant te Amsterdam geworden en stond daar nog in 1806, Naamregister der predt., 's-Grav. 1806, blz. 61.

5) Kerkeraad S. E. aan classis 6 Sept. 1779, oud class. arch., afd. S. E., blz. 35.
} 


\section{NEDERLANDSCHE BOVENWINDSCHE EILANDEN}

Bekker beschuldigd, maar hij zag dat alles thans als onvoorzichtige uitdrukkingen zijner jonge jaren, waarom de classis hem niet meer mocht verstooten. Hij vroeg, dat zij thans ds. Reneman, immers ook op St. Eustatius, zou machtigen om hem in den vollen kerkeraad zijne geloofsbelijdenis af te vorderen. Bleef de classis weigeren, hij zou toch de gemeente in alles trouw blijven tot God hem eens als heilbegeerig dischgenoot zou toelaten tot het genot van het eeuwig feest daarboven ${ }^{1}$ ). Men zou zeggen, een brief om steenen harten te vermurwen. Niets er van. In 1784 was de zaak nog hangende ${ }^{2}$ ). De classis eischte thans eene rondborstige verklaring van gedwaald te hebben en eene schriftelijke opening van 's mans tegenwoordige gevoelens. Met name stelden de broeders er veel belang in te weten, of Runnels nog eenigen twijfel koesterde aan de eeuwige verdoemenis? De aardsche handhaafden zij middelerwijl voor den ketter. Maar Runnels gaf ook hierin toe ${ }^{3}$ ).

Laat ons hopen, dat hij eindelijk zijn wensch verkregen hebbe! $\S 22$. Nog vraagt een ander kerkgeschil onze aandacht. Op St. Kruis stond sinds 1774 de ons reeds welbekende Henr: Müller: Zekere Harm van Tiel had bezwaren tegen het gemeentebeleid van den predikant, en, om deze aangelegenheid te behandelen, zou de kerkeraad van St. Thomas naar St. Kruis overkomen om partijen te hooren. Zoo geschiedde dan ook 4 Maart 1777. De leden van de beide kerkeraden hebben wij reeds vroeger opgegeven ${ }^{4}$ ). Nadat ds. Brandt de zitting geopend had, stond ds. Müller met zijn kerkeraad binnen en verzocht een onderzoek van de beschuldiging door Harm van Tiel ingebracht, dat de gemeente op St. Kruis niet naar eene Hollandsche gemeente geleek. Waarop Van Tiel binnenstond en schriftelijk te kennen gaf: De Dordtsche kerkorde wil dat er avondmaal zij op Paasch-, Pinkster- en Kerstdag ${ }^{5}$ ), maar hier is het elke maand. Het wordt bij de zieken in huis gebracht. Men moet zich bij den predikant aanmelden wanneer men communiceeren wil. Er is op kerstdag j.l. geen avondmaal geweest. Er wordt bij den dienst te veel gezongen. Daarna stonden ds. Müller c.s. binnen en verdedigden zich als volgt. Dat er elke maand avondmaal was, geschiedde op veelvuldig verlan-

$\left.{ }^{1}\right)$ J. Runnels aan ds. Petrus Broes en Ludov. Hamerster te Amsterdam, d.d. St. Eust. 27 Nov. 1782, archief als boven, blz. 40 .

2) Kerkeraad aan classis 18 April 1784, archief als boven, blz. 48.

3) John Runnels aan classis 24 Mei 1785, archief als boven, blz. 50. Over een leertuchtproces tegen een ketterschen schoolmeester te Stellenbosch $a^{\circ} .1769$ mijn Schets v. e. geschied. onzer handelskerken, blz. 93.

4) Boven, blz. 473 .

5) Artik. 63. Hooyer, Oude Kerkordeningen, blz. 456. 
gen. Dat het bij de zieken aan huis werd gebracht, was volgens een besluit van 22 Sept. 1771 , dus vóór ds. Müllers tijd, en daaraan kon hij niet tornen ${ }^{\mathbf{1}}$ ). Bovendien vond hij zelf het ook goed, terwijl er altijd een ouderling en eenige lidmaten, die de psalmen zongen, medegingen ${ }^{2}$ ). De aanmelding voor het avondmaal had hij ingevoerd, omdat er soms negers kwamen, die men niet kende en dus moest ondervragen. Verder diende Van Tiel te bedenken, dat Kerstdag niet altijd op Zondag viel en dat dan bovendien de burgerwachten hun jaarlijksch feestmaal hielden, waarom er dan geen avondmaal was. Maar altijd werd het twaalf maal in het jaar bediend. Ach, betoogde ds. Müller, al deze ceremoniën maken toch niet het wezenlijke van den godsdienst uit! Ze behooren, vond hij, tot die middelmatigheden, waarvan ook in de kerkorde sprake is ${ }^{3}$ ). In Holland was daarin ook wel verschil b.v. in het al of niet knielen van het bruidspaar. En nu het zingen. Ja, daarvoor voelde ds. Müller als Duitscher veel. Het hart der weldenkenden werd er door geroerd, het laten zingen na den zegen geschiedde opdat de menschen niet haastig zouden wegloopen. Het zingen bij den doop van ps. 5 vond hij zeer stichtelijk, "ook” voor de ouders. Hij herinnerde er verder terecht aan, dat in Holland het oude lied, O God, die onze Vader zijt, ook na het gebed mocht gezongen worden ${ }^{4}$ ). Terwijl eindelijk onder het zingen de leeraar een weinig kan uitrusten. Dit laatste argument was zeer „ad hominem”. Overigens verbaast het ons niet van dezen liturg, die aldus den zang vóórstond, elders te hooren, dat hij de nieuwe psalmberijming in zijne gemeente had ingevoerd. Nadat hij aldus zijne zaak verdedigd had, stond Harm van Tiel weder binnen, aan wien de praeses het betoog voorlas en die daarna verklaarde, dat hij geheel overtuigd was en voortaan in liefde met den kerkeraad zou leven. Partijen gaven daarop elkander de hand: een blij eindigend treurspel. Slechts hooren wij met eenige vreeze, dat, zoo sommigen met deze uitspraak niet tevreden mochten zijn, er appel bij de classis in Amsterdam mocht ingebracht worden $\left.{ }^{5}\right)$.

\footnotetext{
1) Aldus reeds in zijn brief van 15 Jan. 1775, waarin hij er bijvoegt dat het den broeders op St. Thomas ten aanstoot is.

${ }^{2}$ ) In Paramaribo gaat na afloop van het avondmaal in de kerk tegenwoordig de predikant met een ouderling in een auto bij de zieken rond, om het avondmaal uit te reiken. Mondel. meded.

3) Art. 85. Hooyer, a. w., blz. 459

4) Art. 69. Hooyer a. w., blz. 457.

5) Kerkeraad van St. Thomas aan classis 8 April 1779 met extract uit de notulen van de vergadering op St. Kruis van 4 Maart 1777 . Oud class. archief afd. St. Thomas, blz. 3. 4a. Wel zeer laat! Misschien heeft ds. Brandt zich in het jaar vergist? Het bericht over de invoering der nieuwe psalmberijming schrijft Müller in zijn brief d.d. St. Kruis 15 Jan. 1775.
} 


\section{8}

NEDERLANDSCHE BOVENWINDSCHE EILANDEN

$\S 23$. De geschiedenis van het kerkgebouw op St. Eustatius is in den aanvang duister. Men leest gewoonlijk dat er reeds in 1672 eene gereformeerde kerk gebouwd werd, die in den orkaan van 1742 te gronde ging. Uit het eigen getuigenis van ds. Kowan is ons echter gebleken, dat er geen kerk was in 1702, dat hij moest preeken in de kortegaard in het fort, dat hij daar als kansel een plank had op twee blokken en dat er zich voor de gemeente vijf banken bevonden ${ }^{1}$ ). Eerst onder zijn opvolger Van Essen maakte men plannen tot verbetering, voor 't geval men den "edelen vrede" behouden mocht ${ }^{2}$ ) en de dominee kon slechts hopen dat daardoor de verchristende wereld op het eiland tot inwendig christendom komen, ordentelijker en eerbaarder en een aangename reuke Christi worden zou ${ }^{3}$ ). Toch duurde het nog tot 1755 vóór de nieuwe kerk was voltooid. Van Essen wijdde haar 2 November van dat jaar in met eene rede naar ps. $84,1-5$ : Hoe lieflijk is uwe woning, Heer der heerschairen ${ }^{4}$ ). Helaas, de groote orkaan van 31 Augustus 1772, die het gansche eiland zoo deerlijk teisterde, verwoestte ook de nieuwe kerk. Jan de Windt vroeg toen aan de Heeren om bouwmateriaal, maar die haastten zich niet en ver: zochten eerst 15 April 1774 om eene nauwkeurige prijsopgave. Daarna echter toonden zij zich tevreden over de bekomen inlichtingen en zonden ten blijk daarvan den commandeur vier okshoofden besten rooden wijn ten geschenke ${ }^{5}$ ). Wanneer de nieuwe kerk toen gereed is gekomen, weet ik niet; op het prentje in een bekend boekje van Rodney's plundering ziet met ook de kerk staan ${ }^{6}$ ). In 1816 zag de predikant-reiziger G. B. Bosch haar, vrij ver van andere huizen, te midden van een ruim kerkhof, hoog en regelmatig gebouwd, met vaste banken voorzien $\left.{ }^{7}\right)$. Enkele jaren later beschrijft Teenstra haar: „zij is een laag, half kruisgebouw, aan het Westeinde met een vierkanten omtrent 70 voeten hoogen toren, het bovenste derde deel van hout met een achtzijdig blauw dak. Dezelve is voorzien van een uurwerk en 4 wijzerplaten. Zoowel de kerk als de toren zijn aan de naar de reede gekeerde Zuidzijde wit bepleisterd, waardoor men haar op Saba zeer duidelijk met het bloote oog kan onderscheiden. De kerk is

1) Boven, I $\S \S 16,18$. Lindesay's kerkbouw, boven II, $\S 24$ gold het herstel van dit lokaal in het fort.

2) Van Essen aan X 20 Febr. 1742, port. no. 5, fol. 523.

3) Van Essen aan classis 27 Octob. 1750, class. arch. als boven, blz. 16.

4) Van Essen aan classis 26 Febr. 1756, class. arch. blz. 20. Dez. aan X 4 Maart

1756, port. no. 7, fol. 716. Zie ook beneden, hoofds. VI, § 13.

s) Heeren X aan Jan de Windt, d.d. 26 Octob. 1774.

6) Engelsche tierannij, Amst. 1781, tegenover blz. 96.

$\left.{ }^{7}\right)$ G. B. Bosch, Reizen in West-Indiën, 1829, I 43. 
van binnen met hout bekleed, zeer donker en er bevindt zich noch orgel noch eenig sieraad in. Dit en de hooge banken en kleine glazen doen het geheel een somber aanzien verkrijgen" $\left.{ }^{1}\right)$. Wij gelooven het gaarne en kunnen deze nuchtere soberheid slechts toeschrijven aan de booze tijden na 1781. Men kon het beter, getuige de geref. kerk op Curaçao en ook die op St. Maarten, een fraaie en nette kerk ${ }^{2}$ ), waarin o.a., vóór de Engelschen ook hier alles kort en klein sloegen, 6 Februari 1781, een prachtige mahoniehouten preekstoel ${ }^{3}$ ). En orgels waren er toch ook. Juist in dezen tijd, 20 December 1774, kreeg de geref. kerk op St. Kruis een nieuw orgel, geschenk van den lutheraan Chartere Stuart, dat ds. Müller toen inwijdde ${ }^{4}$ ). Toen op St. Eustatius de methodistengemeente tot bloei kwam, zooals de zendeling Jonathan Raynar, 1815 - 1818, ons dat beschrijft, met eene jaarlijksche collecte van de blanken alleen van $40 £$, met (later, in 1830) 39 blanken, 120 vrije zwarten en een 300 slaven ${ }^{5}$ ), gebruikte zij, behalve eene eigen kleine kapel, ook de gereformeerde kerk somtijds; doch in den regel deed daar een Engelsch Episcopaalsch predikant dienst, want een Nederlandsch gereformeerd leeraar was er niet meer ${ }^{6}$ ). Thans staat de kerk, van dak, preekstoel en banken beroofd, op den rand van het klif, als een trieste bouwval. Zóó zag Fenger haar, "The Dutch Deformed Church" ").

$\S 24$. Hij vermeldt bij die gelegenheid ook het kerkhof, eene lange rij van graven, met de grafsteenen der oude families De Windt, Heyliger, Van Mussenden en ook de vergeten rustplaats van admiraal Krull. Geen steen herinnert de wereld aan zijn heldenmoed, „maar wat nood, want de wereld komt hier niet, de dooden slapen hier met zichzelven alleen, in een damp die uit den grond schijnt op te komen en de atmosfeer van het eiland doordringt" " $)$. Veel erger is, wat hij bij een volgend bezoek zag: „het oude kerkhof vertoont eene jarenlange verwaarloozing. Het gras overwoekert de verweerde steenen, maar vooral, de profanatie der plaats is afschuwelijk, geen graftombe of zij droeg de sporen

1) M. D. Teenstra, De Ned. W. I. eilanden, 1837, II 328. Collectie Bodel-Nijenhuis, Univ. Bibl. Leid., portef. 369, pl. 22 een prent van G. T. van Paddenburg opgedragen aan ds. Schwiers met de kerk en hoogen toren.

$\left.{ }^{2}\right)$ Reneman aan classis, d.d. St. M. 14 Jan. 1780, oud class. arch., afd. St. M., blz. 18.

3) Reneman aan classis d.d. St. M. 23 Oct. 1781, aldaar blz. 20.

4) Boekzaal 1775, I 745 vlg.

-) Findlay, The history of the Wesl. Method. Mission. Society, Lond. 1921, II $156 \mathrm{~s}$.

') Bosch a. w. I 43. G. van Lennep Coster, Aanteekeningen ged. mijn verblijf in de

W. Indiën 1842, blz. 144.

7) Fred. A. Fenger, Alone in the Caribbean, 1917, pag. 304.

8) T.a.p. 


\section{NEDERLANDSCHE BOVENWINDSCHE EILANDEN}

der negerbevolking, de smadelijkste vervuiling en verwaarloozing. Beter dan maar, begraven te liggen op een eenzamen bergtop of in de diepten der zee" ${ }^{1}$ ). Wat dit alles voor ons nationaal gevoel te schrijnender maakt, is de onaangetaste rust van het oude Joodsche kerkhof, met de Hebreeuwsche letters op de grafsteenen: „geen ontwijding door de negers hier" $\left.{ }^{2}\right)$. Want het is alsof het oude kwaad zich hier wreekt, de oude tijd, toen geen slaaf op de kerkhoven rusten mocht, maar zijn lijk in de rimboe onder den grond werd gestopt. Wij zagen reeds dat er op St. Maarten twee kerkhoven waren ${ }^{3}$ ). Mochten daar aanvankelijk ook de christelijke negers en mulatten of althans de gedoopte begraven worden, op het eind der 18de eeuw verbood de kerkeraad dat voor alle negers en voor wie van de kleur waren, vrijen of slaven, gedoopten of ongedoopten. $\mathrm{Zij}$ mochten niet tusschen de anderen rusten, maar moesten hunne dooden begraven op een door de regeering aangewezen stuk woesten grond $\left.{ }^{4}\right)$. Wat de christenen aangaat, zij mochten private graven op de kerkhoven laten aanleggen van $7 \times 8$ voet voor $f 25$ aan de armenkas ${ }^{5}$ ). Bij begrafenissen werd de klok geluid en gold het, op St. Eustatius, een persoon van eenige beteekenis, dan ging de commandeur eerst achter de baar, daarna de predikant, daarna de kapitein der burgerij. Lijkbidders waren er niet ${ }^{6}$ ).

$\S 25$. Van de pastorie van ds. Kowan, die hij met een voorschot uit de diakoniekas voor zich gebouwd had, hebben wij gesproken ${ }^{7}$ ). Fraai of geriefelijk was het niet, en ds. van Essen kreeg een nieuw „pastoraat huis", dat hij „met zeer veel satisfactie en gemak" bewoonde ${ }^{8}$ ).

(Wordt vervolgd.)

1) Fred. A. Fenger, The cruise of Diablesse, 1926, p. 261

2) T.a.p.

3) Boven, blz. 475 .

4) Not. kerker. St. Maarten 19 Aug. 1791, sub 4. R. A. Invent. no. 533.

5) Aldaar, sub. 5

-) Ds. van Essen had in zijn dagen over dien voorrang een strijd met Ellis, den kapitein der burgerij, die hem bij de begrafenissen wilde „voordringen”, wat hij, ofschoon „geen soeker van ijdele eer”, zich niet wilde laten welgevallen. Hij zou ook wel twee goede mannen tot lijkbidders benoemd willen zien, maar, als hij dit zou voordragen, zou de heer Ellis zeggen, dat hij was gekomen, niet om wetten te maken maar om ze te ontvangen. Van Essen aan X 29 Juni 1744, port. no. 6, fol. 198.

7) Boven II, § 4 .

8) Van Essen aan classis 14 Sept. 1761, oud class. archief afd. S. E., blz. 24. 